\title{
Penerapan Algoritma Apriori untuk Market Basket Analysis
}

\author{
NUR FITRIANTI FAHRUDIN ${ }^{1}$ \\ ${ }^{1}$ Institut Teknologi Nasional Bandung \\ Email: nurfitrianti@itenas.ac.id
}

Received 30 November 201x | Revised 30 Desember 201x | Accepted 30 Januari 201x

\begin{abstract}
ABSTRAK
Pemanfaatan teknik data mining saat ini dapat membantu para pemilik bisnis untuk meningkatkan penjualan produk mereka. Salah satu teknik yang sangat dikenal adalah analisis asosiasi. Analisis asosiasi bertujuan untuk menemukan hubungan antara barang-barang yang dibeli oleh pelanggan. Analisis asosiasi semacam ini biasa dikenal sebagai market basket analysis. Market basket analysis menggunakan data pelanggan yang selama ini disimpan didalam basis untuk menemukan informasi baru didalamnya. Algoritma Apriori merupakan algoritma untuk melakukan market basket analisis, yang bertujuan untuk menemukan barang yang paling sering dibeli. Algoritma Apriori ini menghasilkan sebuah aturan asosiasi yang bermanfaat bagi pelaku bisnis. Untuk memilih aturan asosasi yang paling kuat diperlukan perhitungan lift ratio. Dengan menghitung lift ratio dari setiap aturan asosiasi, dapat diketahui aturan asosiasi yang valid dan paling kuat. Dengan melakukan analisis asosiasi, dapat diketahui bahwa data pelanggan dapat dimanfaatkan sebagai masukan kepada pemilik bisnis untuk menentukan strategi penjualan bagi bisnis mereka.
\end{abstract}

Kata kunci: Algoritma Apriori, Market Basket Analysis, Asosisasi

\begin{abstract}
Data mining techniques today can help business owners to increase sales of their products. One well-known technique is association analysis. Association analysis aims to find relationships between items purchased by customers. This kind of association analysis is commonly known as market basket analysis. Market basket analysis uses customer data that has been stored on the base to find new information in it. A priori algorithm is an algorithm for doing market basketball analysis, which aims to find the items that are most often purchased. This a priori algorithm produces an association rule that is beneficial for business people. To choose the strongest association rule, it is necessary to calculate the elevator ratio. By calculating the elevator ratio of each association rule, you can find the valid and strongest association rules. By conducting association analysis, it can be seen that customer data can be used as input for business owners to determine sales strategies for their business.
\end{abstract}

Keywords: Apriori Algorithm, Market Basket Analysis, Association 


\section{PENDAHULUAN}

Informasi dan data yang disimpan berkat teknologi saat ini, semakin hari memiliki volume yang cukup besar. Teknologi yang ada juga telah mampu memberikan kontribusi untuk menghasilkan informasi yang berguna dengan mengolah data yang cukup besar sehingga memiliki manfaat bagi penggunanya. Data mining merupakan tahapan yang penting dalam proses penemuan pengetahuan (knowledge discovery). Data mining adalah metode cerdas yang diterapkan untuk mengekstrak suatu pola data (Han, Kamber, \& Pei, 2012).

Para peneliti terdahulu telah menemukan bahwa data mining dapat dilakukan pada berbagai repositori data dan informasi (Han et al., 2012). Terdapat beberapa teknik data mining yang biasa digunakan, salah satunya adalah asosiasi. Pemilihan teknik data mining yang digunakan, menentukan jenis pola yang akan ditemukan pada saat melakukan data mining. Ketersediaan basis data yang memuat transaksi pembelian konsumen pada suatu toko, akhirnya mendorong para peneliti untuk mengembangkan teknik yang mampu menemukan asosiasi antar produk-produk yang dibeli oleh konsumen (Listriani, Setyaningrum, \& M.A, 2016). Salah satu contohnya adalah data transaksi pada suatu supermarket. Asosiasi merupakan teknik data mining yang bertujuan untuk menemukan suatu pola yang sering muncul dalam sebuah data (Han et al., 2012). Pola tersebut dapat berupa frekuensi kemunculan suatu item, urutan atau struktur. Frekuensi kemunculan suatu item biasanya merujuk pada satu item yang sering muncul bersamaan dalam satu set data transaksional sebagai contoh susu dan kopi, dimana susu dan kopi merupakan item yang sering dibeli secara bersamaan disebuah supermarket oleh banyak pelanggan.

Analisis asosiasi sering kali digunakan untuk menganalisis keranjang belanja pelanggan pada suatu supermarket, oleh karena itu analisis asosiasi sering disebut sebagai istilah Market Basket Analysis (MBA). MBA pada dasarnya menggunakan data transaksional para konsumen dalam mempelajari pola pembelian serta mencari kemungkinan terjadinya crossselling (Wicaksana, 2013). MBA bertujuan untuk memanfaatkan data transaksi para konsumen untuk mencari taktik pemasaran yang tepat sehinggan dapat meningkatkan penjualan toko. Analisis ini merupakan suatu langkah yang tepat untuk diambil, mengingat persaingan di industri yang kian ketat. Jika Manajer salah dalam mengambil analisis bisa saja terjadi penurunan pembelian oleh konsumen. Para manajer perlu menyadari pemanfaatan teknologi yang kian canggih sehingga data konsumen dapat disimpan dengan baik. Manajer saat ini memiliki miliyaran informasi mengenai konsumen mereka. Pada dasarnya manajer dapat menerapkan analisis asosiasi pada data yang mereka miliki saat ini. Sehingga pada paper ini penulis menunjukan tahapan yang biasa dilakukan dalam melakukan Market Basket Analysis.

Terdapat beberapa metode yang biasa dilakukan untuk melakukan asosiasi diantaranya adalah algoritma Apriori dan FP-Growth (Kasus, Pt, Gunadi, \& Sensuse, 2012). Algoritma Apriori adalah algoritma klasik yang biasa digunakan untuk melakukan asosiasi, akan tetapi algoritma ini memiliki kelemahan karena memakan waktu yang cukup besar. Hal ini dikarenakan algoritma Apriori perlu melakukan scan kedalam basis data pada setiap iterasinya, sehingga semakin banyak iterasi semakin besar pula waktu yang dibutuhkan. Para peneliti akhirnya mengembangan algoritma baru yaitu FP-Growth, yang mana kekurangan dari algoritma Apriori akhirnya diperbaiki oleh algoritma FP-Growth. Pada artikel ini penulis menuliskan cara melakukan analisis untuk menemukan aturan asosiasi menggunakan algoritma Apriori. 


\section{METODOLOGI}

\subsection{Aturan Asosiasi}

Analisis asosiasi ini biasa dilakukan untuk membuat komputer menemukan aturan asosiasi dengan mencari keterkaitan antara item satu dengan yang lainnya dalam suatu data set atau dalam hal ini transaksi. Algoritma yang biasa digunakan untuk membuat aturan asosiasi menggunakan data latih sebagai cara untuk menghasilkan pengetahuan. Pengetahuan ini dapat berupa informasi mengenai item atau produk yang sering dibeli dalam waktu bersamaan. Aturan asosiasi merupakan sebuah pengetahuan yang dihasilkan dari analisis asosiasi. Aturan ini dihitung dari data yang sifatnya probabilistik (Sepri \& Afdal, 2017). Aturan asosiasi adalah sebuah ekspresi implikasi dari bentuk $X \rightarrow Y$, atau sebagai contoh jika ditermahkan menjadi "Jika membeli susu pasti membeli kopi". Dalam menentukan aturan asosiasi, terdapat suatu interestingness measure (ukuran ketertarikan) yang didapatkan dari hasil pengolahan data dengan menghitung nilai support dan confidence. Nilai support dan confidence berfungsi untuk menentukan ketertarikan aturan asosiasi yang nantinya dibandingkan dengan batasan (threshold). Batasan yang ditentukan oleh pengguna tersebut biasanya disebut minimum support dan minimum confidence.

Metodologi dalam melakukan analisis asosiasi terbagi kedalam dua tahapan (Kusrini, 2009):

\section{Analisis pola frekuensi tinggi}

Analisis pola frekuensi tinggi adalah suatu langkah yang dilakukan dalam rangka mencari kombinasi item yang memenuhi nilai minimum support yang telah ditentukan untuk suatu data set. Nilai support dari suatu item dapat diperoleh mengunakan Persamaan 1.

$$
\operatorname{Support}(A)=\frac{\text { Jumlah transaksi yang mengandung } A}{\text { Total Transaksi }}
$$

Atau gunakan Persamaan 2 untuk menghitung support dua buah item.

$$
\text { Support }(A \cap B)=\frac{\text { Jumlah transaksi yang mengandung } A \text { dan } B}{\text { Total Transaksi }}
$$

\section{Pembentukan aturan asosiatif}

Pembentukan aturan asosiatif dilakukan setelah seluruh pola frekuensi tinggi ditemukan. Selanjutnya barulah mencari aturan asosiatif yang memenuhi syarat nilai minimum confidence. Jika support adalah presentasi kemunculan item A dan B secara bersamaan, Confidence adalah seberapa seringnya suatu item B muncul dalam transaksi yang 
mengandung A. Nilai confidence dari suatu item dapat dicari dengan menggunakan Persamaan 3.

$$
\text { Confidence }=P(B \mid A)=\frac{\text { Jumlah transaksi yang mengandung } A \text { dan } B}{\text { Jumlah transaksi mengandung } A}
$$

\subsection{Algoritma Apriori}

Algoritma Apriori adalah suatu algoritma yang sudah sangat dikenal dalam melakukan pencarian kombinasi dari sebuah itemsetyang memiliki jumlah kemunculan tertentu sesuai dengan kriteria yang telah ditentukan (Widiastuti \& Sofi, 2014). Algoritma Apriori menggunakan pengetahuan mengenai frekuensi dari itemset yang telah diketahui sebelumnya, untuk dijadikan informasi pada iterasi selanjutnya. Algoritma Apriori memperhatikan nilai minimum support dalam menentukan kandidat-kandidat yang mungkin muncul (Erwin, 2009).

\section{Berikut adalah langkah-langkah dari algoritma Apriori (Han et al., 2012).}

1. Pada iterasi pertama, setiap item merupakan bagian dari himpunan item yang terdiri atas 1 item (kandidat 1-itemset). Algoritma ini melakukan scan terhadap seluruh transaksi dalam data set untuk menghitung jumlah kemunculan dari setiap item atau nilai support.

2. Tentukan nilai minimum support. Kandidat 1 -itemset yang memiliki nilai support diatas nilai minimum support dipilih menjadi himpunan 1-itemset atau pola frekuensi tinggi.

3. Pada iterasi kedua, setiap item pada iterasi sebelumnya dikombinasikan untuk memperoleh kandidat 2-itemset. Kemudian scan terhadap dataset dilakukan kembali untuk menghitung nilai support dari kombinasi 2-itemset. Kandidat 2itemset yang memenuhi nilai minimum support dipilih sebagai pola frekuensi tinggi.

4. Pada iterasi ketiga, dilakukan kombinasi dari hasil dari iterasi kedua yaitu himpunan 2-itemset untuk mendapatkan kandidat 3-itemset. Kemudian scan kembali ke dalam dataset untuk menghitung nilai support dari kandidat 3-itemset. Kandidat 3-itemset yang memenuhi nilai minimum support dipilih sebagai pola frekuensi tinggi dari kandidat.

5. Lakukan iterasi selanjutnya, jika masih terdapat kombinasi k-itemset yang dapat dibentuk dan memenuhi nilai minimum support. Tetapkan nilai support dari kitemset dan pilih k-itemset yang memenuhi nilai minimum support.

6. Hitung nilai confidence dari setiap aturan asosiasi $A \rightarrow B$, ambil aturan asosiasi yang memenuhi syarat nilai minimum confidence yang telah ditentukan.

\subsection{Lift Ratio}

Pemilihan aturan asosiasi tidak hanya melihat nilai aturan yang memiliki nilai confidence paling tinggi, hal ini dikarenakan pemilihan aturan berdasarkan nilai confidence dapat menipu. Jika nilai support yang dimiliki antecendent atau consequent tinggi, maka aturan asosiasi dapat memiliki confidence yang tinggi. Untuk mengukur aturan mana yang lebih baik adalah dengan membandingkan antara nilai confidence untuk suatu aturan dibagi dengan expected confidence (nilai confidence yang diharapkan). Hal ini merupakan langkah untuk menghitung lift ratio. Lift ratio adalah suatu ukuran untuk mengetahui kekuatan aturan asosisasi yang telah terbentuk (Fauzy, rahmat S, \& Asror, 2016). Jika suatu aturan memiliki 
confidence yang tinggi, berarti aturan tersebut memberikan ciri suatu kekuatan dari aturan asosiasi. Untuk menghitung lift ratio digunakan Persamaan 4.

$$
\text { Lift Ratio }=\frac{\text { Confidence }}{\text { Expected Confidence }}
$$

Untuk menghitung nilai dari expected confidence dapat dihitung menggunakan Persamaan 5.

$$
\text { Expected Confidence }=\frac{\text { Jumlah transaksi yang mengandung } B}{\text { Total Transaksi }}
$$

Aturan asosiasi yang memiliki nilai Lift ratio lebih besar dari 1 menunjukan adanya manfaat dari aturan tersebut. Lebih tinggi nilai lift ratio, lebih besar kekuatan asosasianya (santosa, 2007).

\section{HASIL}

Pada artikel ini analisa yang digunakan menggunakan algoritma Apriori. Data sample yang digunakan adalah contoh studi kasus yang dibuat sendiri dengan tujuan untuk lebih memudahkan pembaca dalam memahami studi kasus ini. Berikut pada Tabel 1 adalah studi kasus mengenai transaksi disuatu supermarket.

Tabel 1. Studi Kasus

\begin{tabular}{|c|c|}
\hline ID_Transaksi & Item_yang_dibeli \\
\hline 1 & mentega, terigu, telur, gula \\
\hline 2 & mentega, telur, baking soda \\
\hline 3 & gula, terigu, telur \\
\hline 4 & terigu, baking soda, gula \\
\hline 5 & gula, telur \\
\hline
\end{tabular}

Proses berikutnya adalah memilih item yang memenuhi minimal support yang telah ditentukan. Pada studi kasus ini minimal support yang ditentukan adalah $40 \%$.

Pada iterasi pertama yang dilakukan adalah mencari kombinasi satu item, hal ini dilakukan dengan cara mendaftarkan semua item yang terdapat didalam dataset. Selanjutnya setiap item dihitung nilai supportnya. Setelah semua item dihitung nilai supportnya maka item yang memiliki nilai yang lebih besar sama dengan nilai minimum supportnya dipilih. Berikut pada Tabel 2 hasil dari iterasi pertama.

Tabel 2. Kandidat 1-Itemset

\begin{tabular}{|c|l|c|c|}
\hline No & \multicolumn{1}{|c|}{ Nama Barang } & \multicolumn{2}{c|}{ Support } \\
\hline 1 & mentega & $2 / 5$ & $40 \%$ \\
\hline 2 & terigu & $3 / 5$ & $60 \%$ \\
\hline 3 & telur & $4 / 5$ & $80 \%$ \\
\hline 4 & gula & $4 / 5$ & $80 \%$ \\
\hline 5 & baking soda & $2 / 5$ & $40 \%$ \\
\hline
\end{tabular}


Hasil dari iteras pertama yang ditunjukan oleh Tabel 2 dipilih item yang memiliki minimal support sebesar $40 \%$, setelah itu dibentuklah kombinasi dua item. Berikut pada Tabel 3 adalah hasil dari iterasi kedua.

Tabel 3. Kandidat 2-Itemset

\begin{tabular}{|c|l|c|c|}
\hline No & \multicolumn{1}{|c|}{ Nama Barang } & \multicolumn{2}{c|}{ Support } \\
\hline 1 & mentega, terigu & $1 / 5$ & $20 \%$ \\
\hline 2 & mentega, telur & $2 / 5$ & $40 \%$ \\
\hline 3 & mentega, gula & $1 / 5$ & $20 \%$ \\
\hline 4 & mentega, baking soda & $1 / 5$ & $20 \%$ \\
\hline 5 & terigu, telur & $2 / 5$ & $40 \%$ \\
\hline 6 & terigu, gula & $3 / 5$ & $60 \%$ \\
\hline 7 & terigu, baking soda & $1 / 5$ & $20 \%$ \\
\hline 8 & telur, gula & $2 / 5$ & $40 \%$ \\
\hline 9 & telur, baking soda & $1 / 5$ & $20 \%$ \\
\hline 10 & gula, baking soda & $1 / 5$ & $20 \%$ \\
\hline
\end{tabular}

Pada Tabel 3 tidak semua kombinasi dua item memenuhi minimum support yang telah ditentukan. Maka pola item seperti pada nomor $1,3,4,7,9,10$ pada Tabel 3 ini tidak dipilih. Berikut pada Tabel 4 ditunjukan pola frekuensi tinggi diatas minimum support untuk 2-itemset.

Tabel 4. Pola 2-Itemset

\begin{tabular}{|c|l|c|c|}
\hline No & \multicolumn{1}{|c|}{ Nama Barang } & \multicolumn{2}{|c|}{ Support } \\
\hline 1 & mentega, telur & $2 / 5$ & $40 \%$ \\
\hline 2 & terigu, telur & $2 / 5$ & $40 \%$ \\
\hline 3 & terigu, gula & $3 / 5$ & $60 \%$ \\
\hline 4 & telur, gula & $2 / 5$ & $40 \%$ \\
\hline
\end{tabular}

Tabel 4 selanjutnya digunakan sebagai referensi untuk melakukan kombinasi 3 itemset. Hasil dari kombinasi ini ditunjukan oleh Tabel 5.

Tabel 5. Kandidat 3-Itemset

\begin{tabular}{|c|l|c|c|}
\hline No & \multicolumn{1}{|c|}{ Nama Barang } & \multicolumn{2}{|c|}{ Support } \\
\hline 1 & gula, terigu, telur & $2 / 5$ & $40 \%$ \\
\hline 2 & mentega, terigu, telur & $1 / 5$ & $20 \%$ \\
\hline 3 & mentega, terigu, gula & $1 / 5$ & $20 \%$ \\
\hline 4 & mentega, terigu, baking soda & $0 / 5$ & $0 \%$ \\
\hline 5 & mentega, telur, gula & $1 / 5$ & $20 \%$ \\
\hline 6 & mentega, telur, baking soda & $1 / 5$ & $20 \%$ \\
\hline 9 & terigu, telur, baking soda & $0 / 5$ & $0 \%$ \\
\hline 10 & terigu, gula, baking soda & $1 / 5$ & $20 \%$ \\
\hline 11 & telur, gula, baking soda & $0 / 5$ & $0 \%$ \\
\hline
\end{tabular}


Sama seperti pada iterasi sebelumnya, hanya kandidat item yang memenuhi minimum support yang dipilih. Berikut pada Tabel 6 adalah pola frekuensi tinggi diatas minimum support untuk 3-itemset.

Tabel 6. Pola 3-Itemset

\begin{tabular}{|c|l|c|c|}
\hline No & \multicolumn{1}{|c|}{ Nama Barang } & \multicolumn{2}{|c|}{ Support } \\
\hline 1 & gula, terigu, telur & $2 / 5$ & $40 \%$ \\
\hline
\end{tabular}

Karena pada iterasi ketiga masih terdapat data yang memenuhi minimum support maka dilanjutkan kepada iterasi ke empat. Berikut pada Tabel 7 adalah hasil dari iterasi ke empat.

Tabel 7. Kandidat 4-Itemset

\begin{tabular}{|c|l|c|c|}
\hline No & \multicolumn{1}{|c|}{ Nama Barang } & \multicolumn{2}{c|}{ Support } \\
\hline 1 & mentega, terigu, telur, gula & $1 / 5$ & $20 \%$ \\
\hline 2 & mentega, terigu, telur, baking soda & $0 / 5$ & $0 \%$ \\
\hline 3 & mentega, terigu, gula, baking soda & $0 / 5$ & $0 \%$ \\
\hline 4 & mentega, telur, gula, baking soda & $0 / 5$ & $0 \%$ \\
\hline 5 & terigu, telur, gula, baking soda & $0 / 5$ & $0 \%$ \\
\hline
\end{tabular}

Pada Tabel 7 tidak terdapat lagi kombinasi item yang memenuhi minimum support, sehinggan tidak ada data yang bisa dibentuk untuk k-itemset berikutnya.

Pada tahap pertama nilai support dari masing-masing item dicari, maka terbentuklah aturan yang memenuhi minimum support $40 \%$. Setelah semua pola kombinasi dan nilai support ditemukan, selanjutnya adalah mencari aturan asosiasi yang memenuhi nilai confidence. Berikut pada Tabel 8 adalah kandidat aturan asosiatif dengan nilai minimum confidence $60 \%$.

Tabel 8. Kadidat aturan asosiatif

\begin{tabular}{|l|c|l|c|c|c|c|}
\hline No & $\begin{array}{l}\text { Jumlah } \\
\text { Barang }\end{array}$ & Nama Barang & \multicolumn{2}{|c|}{ Support } & \multicolumn{2}{c|}{ Confident } \\
\hline 1 & 1 & mentega & $2 / 5$ & $40 \%$ & & $0 \%$ \\
\hline 2 & 1 & terigu & $3 / 5$ & $60 \%$ & & $0 \%$ \\
\hline 3 & 1 & telur & $4 / 5$ & $80 \%$ & & $0 \%$ \\
\hline 4 & 1 & gula & $4 / 5$ & $80 \%$ & & $0 \%$ \\
\hline 5 & 1 & baking soda & $2 / 5$ & $40 \%$ & & $0 \%$ \\
\hline 6 & 2 & mentega $\rightarrow$ terigu & $1 / 5$ & $20 \%$ & $1 / 2$ & $50 \%$ \\
\hline 7 & 2 & mentega $\rightarrow$ telur & $2 / 5$ & $40 \%$ & 1 & $100 \%$ \\
\hline 8 & 2 & mentega $\rightarrow$ gula & $1 / 5$ & $20 \%$ & $1 / 2$ & $50 \%$ \\
\hline 9 & 2 & mentega $\rightarrow$ baking soda & $1 / 5$ & $20 \%$ & $1 / 2$ & $50 \%$ \\
\hline 10 & 2 & terigu $\rightarrow$ telur & $2 / 5$ & $40 \%$ & $2 / 3$ & $67 \%$ \\
\hline 11 & 2 & terigu $\rightarrow$ gula & $3 / 5$ & $60 \%$ & $2 / 3$ & $67 \%$ \\
\hline 12 & 2 & terigu $\rightarrow$ baking soda & $1 / 5$ & $20 \%$ & $1 / 3$ & $33 \%$ \\
\hline
\end{tabular}




\begin{tabular}{|l|c|l|c|c|c|c|}
\hline No & $\begin{array}{l}\text { Jumlah } \\
\text { Barang }\end{array}$ & Nama Barang & \multicolumn{2}{l|}{ Support } & \multicolumn{2}{l|}{ Confident } \\
\hline 13 & 2 & telur,gula & $2 / 5$ & $40 \%$ & $3 / 4$ & $75 \%$ \\
\hline 14 & 2 & telur $\rightarrow$ baking soda & $1 / 5$ & $20 \%$ & $1 / 4$ & $25 \%$ \\
\hline 15 & 2 & gula $\rightarrow$ baking soda & $1 / 5$ & $20 \%$ & $1 / 4$ & $25 \%$ \\
\hline 16 & 3 & gula, terigu $\rightarrow$ telur & $2 / 5$ & $40 \%$ & 1 & $100 \%$ \\
\hline 17 & 3 & mentega, terigu $\rightarrow$ telur & $1 / 5$ & $20 \%$ & $1 / 2$ & $50 \%$ \\
\hline 18 & 3 & mentega, terigu $\rightarrow$ gula & $1 / 5$ & $20 \%$ & $1 / 2$ & $50 \%$ \\
\hline 19 & 3 & mentega, terigu $\rightarrow$ baking soda & $0 / 5$ & $0 \%$ & $0 / 2$ & $0 \%$ \\
\hline 20 & 3 & mentega, telur $\rightarrow$ gula & $1 / 5$ & $20 \%$ & $0 / 2$ & $0 \%$ \\
\hline 21 & 3 & mentega, telur $\rightarrow$ baking soda & $1 / 5$ & $20 \%$ & $1 / 2$ & $50 \%$ \\
\hline 22 & 3 & gula, telur $\rightarrow$ terigu & $2 / 5$ & $40 \%$ & $2 / 3$ & $67 \%$ \\
\hline 23 & 3 & telur, terigu $\rightarrow$ gula & $2 / 5$ & $40 \%$ & 1 & $100 \%$ \\
\hline 24 & 3 & terigu, telur $\rightarrow$ baking soda & $0 / 5$ & $0 \%$ & $0 / 4$ & $0 \%$ \\
\hline 25 & 3 & terigu, gula $\rightarrow$ baking soda & $1 / 5$ & $20 \%$ & $1 / 4$ & $25 \%$ \\
\hline 26 & 3 & telur, gula $\rightarrow$ baking soda & $0 / 5$ & $0 \%$ & $0 / 4$ & $0 \%$ \\
\hline 27 & 4 & mentega, terigu, telur $\rightarrow$ gula & $1 / 5$ & $20 \%$ & $1 / 2$ & $50 \%$ \\
\hline 28 & 4 & mentega, terigu, telur $\rightarrow$ baking soda & $0 / 5$ & $0 \%$ & $0 / 2$ & $0 \%$ \\
\hline 29 & 4 & mentega, terigu, gula $\rightarrow$ baking soda & $0 / 5$ & $0 \%$ & $0 / 2$ & $0 \%$ \\
\hline 30 & 4 & mentega, telur, gula $\rightarrow$ baking soda & $0 / 5$ & $0 \%$ & $0 / 2$ & $0 \%$ \\
\hline 31 & 4 & terigu, telur, gula $\rightarrow$ baking soda & $0 / 5$ & $0 \%$ & $0 / 4$ & $0 \%$ \\
\hline
\end{tabular}

Berdasarkan kepada Tabel 8 yang telah diseleksi dengan hanya memilih kombinasi yang memiliki nilai minimimum confidence $60 \%$, maka hasil dari analisis menggunakan algoritma Apriori ini ditunjukan oleh Tabel 9.

Tabel 9. Aturan Asosiasi

\begin{tabular}{|l|c|l|c|c|c|c|}
\hline No & Jumlah Barang & Nama Barang & \multicolumn{2}{|l|}{ Support } & \multicolumn{2}{l|}{ Confidence } \\
\hline 1 & 2 & mentega $\rightarrow$ telur & $2 / 5$ & $40 \%$ & $2 / 2$ & $100 \%$ \\
\hline 2 & 2 & terigu $\rightarrow$ telur & $2 / 5$ & $40 \%$ & $2 / 3$ & $67 \%$ \\
\hline 3 & 2 & telur $\rightarrow$ terigu & $2 / 5$ & $40 \%$ & $3 / 4$ & $75 \%$ \\
\hline 4 & 2 & terigu $\rightarrow$ gula & $3 / 5$ & $60 \%$ & $2 / 3$ & $67 \%$ \\
\hline 5 & 2 & gula $\rightarrow$ telur & $2 / 5$ & $40 \%$ & $3 / 4$ & $75 \%$ \\
\hline 6 & 2 & telur $\rightarrow$ gula & $2 / 5$ & $40 \%$ & $3 / 4$ & $75 \%$ \\
\hline 7 & 3 & gula, terigu $\rightarrow$ telur & $2 / 5$ & $40 \%$ & $2 / 2$ & $100 \%$ \\
\hline 8 & 3 & gula, telur $\rightarrow$ terigu & $2 / 5$ & $40 \%$ & $2 / 3$ & $67 \%$ \\
\hline 9 & 3 & telur, terigu $\rightarrow$ gula & $2 / 5$ & $40 \%$ & $2 / 2$ & $100 \%$ \\
\hline
\end{tabular}

Pada Tabel 10 merupakan hasil untuk perhitungan lift ratio dari setiap aturan asosiasi yang telah memenuhi nilai minimum confidence. Lift ratio adalah salah satu cara untuk melihat kuat tidaknya suatu aturan dalam algoritma asosiasi.

Tabel 10. Lift Ratio untuk setiap Aturan

\begin{tabular}{|l|l|l|l|l|l|}
\hline No & Nama Barang & Support & Confidence & EC & $\begin{array}{l}\text { Lift } \\
\text { Ratio }\end{array}$ \\
\hline
\end{tabular}




\begin{tabular}{|l|l|l|l|l|l|}
\hline No & Nama Barang & Support & Confidence & EC & $\begin{array}{l}\text { Lift } \\
\text { Ratio }\end{array}$ \\
\hline 1 & mentega $\rightarrow$ telur & $40 \%$ & $100 \%$ & $80 \%$ & 1,25 \\
\hline 2 & terigu $\rightarrow$ telur & $40 \%$ & $67 \%$ & $80 \%$ & 0,8375 \\
\hline 3 & telur $\rightarrow$ terigu & $40 \%$ & $75 \%$ & $60 \%$ & 1,25 \\
\hline 4 & terigu $\rightarrow$ gula & $60 \%$ & $67 \%$ & $80 \%$ & 0,8375 \\
\hline 5 & gula $\rightarrow$ telur & $40 \%$ & $75 \%$ & $80 \%$ & 0,9375 \\
\hline 6 & telur $\rightarrow$ gula & $40 \%$ & $75 \%$ & $80 \%$ & 0,9375 \\
\hline 7 & gula, terigu $\rightarrow$ telur & $40 \%$ & $100 \%$ & $80 \%$ & 1,25 \\
\hline 8 & gula, telur $\rightarrow$ terigu & $40 \%$ & $67 \%$ & $60 \%$ & 1,12 \\
\hline 9 & telur, terigu $\rightarrow$ gula & $40 \%$ & $100 \%$ & $80 \%$ & 1,25 \\
\hline
\end{tabular}

Dapat dilihat terdapat beberapa item yang memiliki nilai confidence $100 \%$, hal ini berarti konsumen yang membeli item A pasti $100 \%$ membeli item B. Sebagai contoh \{telur,terigu $\rightarrow$ \{gula\} yang memiliki nilai support $40 \%$ dan confidence $100 \%$, dapat diterjemahkan menjadi seorang konsumen yang membeli telur dan terigu memiliki kemungkinan $100 \%$ untuk membeli gula, dimana aturan ini cukup signifikan karena mewakili $40 \%$ dari transaksi yang melibatkan item mentega selama ini. Untuk menentukan aturan asosiasi yang pilih adalah dengan mengambil aturan asosiasi yang memiliki nilai lift ratio paling tinggi. Selanjutnya hasil dari aturan asosiasi ini dapat digunakan oleh manajer toko untuk dipilih, salah satunya sebagai strategi promosi untuk toko mereka.

Untuk memudahkan pembentukan aturan asosiasi ini, terdapat salah satu tools yang dapat digunakan yaitu Rapid Miner. RapidMiner adalah sebuah tools yang bersifat open source yang dapat digunakan untuk melakukan analisis data mining, text mining dan analisis prediksi (Wicaksana, 2013). Untuk dapat melakukan analisis asosiasi terlebih diperlukan extention dari WEKA yang dapat di unduh pada marketplace rapid miner.

Langkah pertama yang dilakukan adalah membuat mentransformasikan data set yang dimiliki. Pada Studi kasus ini data pada Tabel 1 dirubah menjadi bentuk tabular seperti yang ditunjukan oleh Gambar 1.

\begin{tabular}{|c|c|c|c|c|}
\hline Mentega & Terigu & Telur & Gula & Baking soda \\
\hline 1 & 1 & 1 & 0 & 0 \\
\hline 1 & 0 & 1 & 0 & 1 \\
\hline 0 & 1 & 1 & 1 & 0 \\
\hline 0 & 1 & 0 & 1 & 1 \\
\hline 0 & 0 & 1 & 1 & 0 \\
\hline
\end{tabular}

\section{Gambar 1. Data set}

Langkah selanjutnya adalah pengolahan data menggunakan rapid miner. Terdapat beberapa operator yang digunakan, operator ini dapat dilihat pada Gambar 2. 


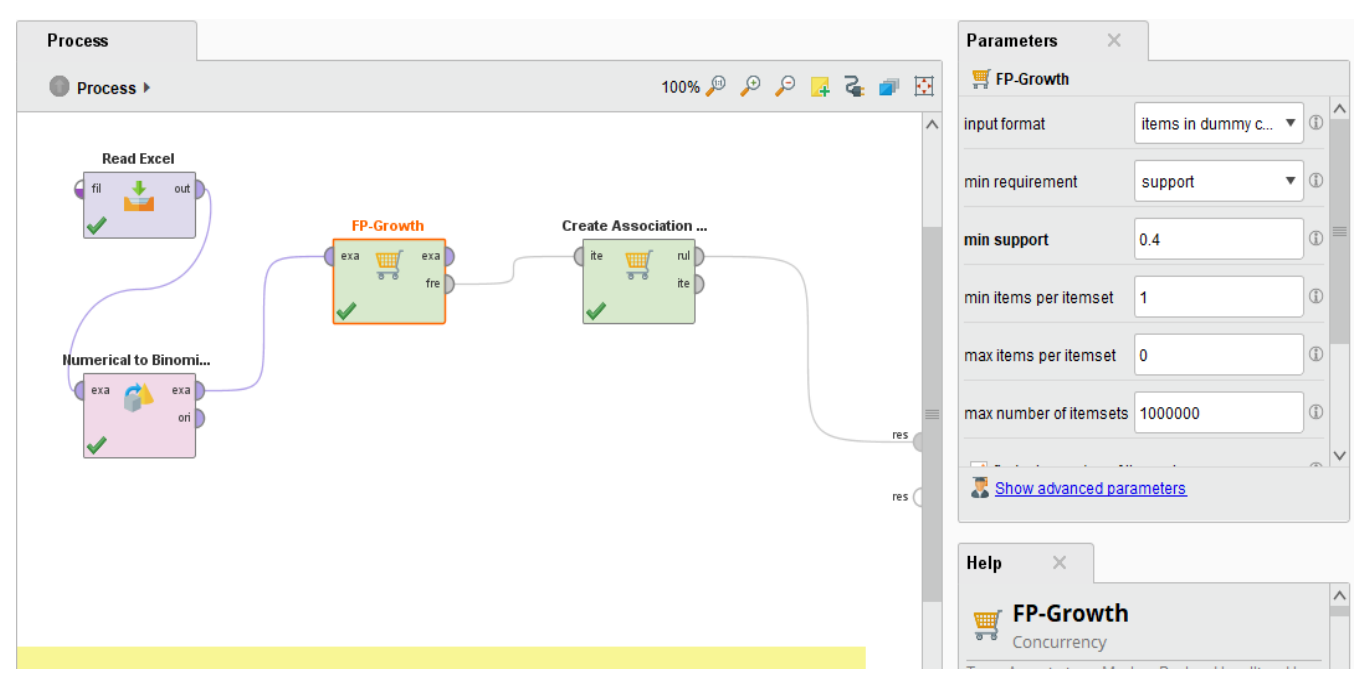

Gambar 2. Mengatur Minimal support

Setelah semua operator dihubungkan, selanjutnya adalah mengatur nilai minimum support yang diinginkan. Untuk mengatur nilai minimum support caranya dengan memilih operator FP-Growth pada tab parameter masukan nilai minimum support yang diinginkan. Implementasi yang dilakukan pada rapid miner digunakan algoritma FP-growth. Kemudian untuk mengatur nilai confidence, pilih operator create association rules pada tab parameter masukan nilai confidence.

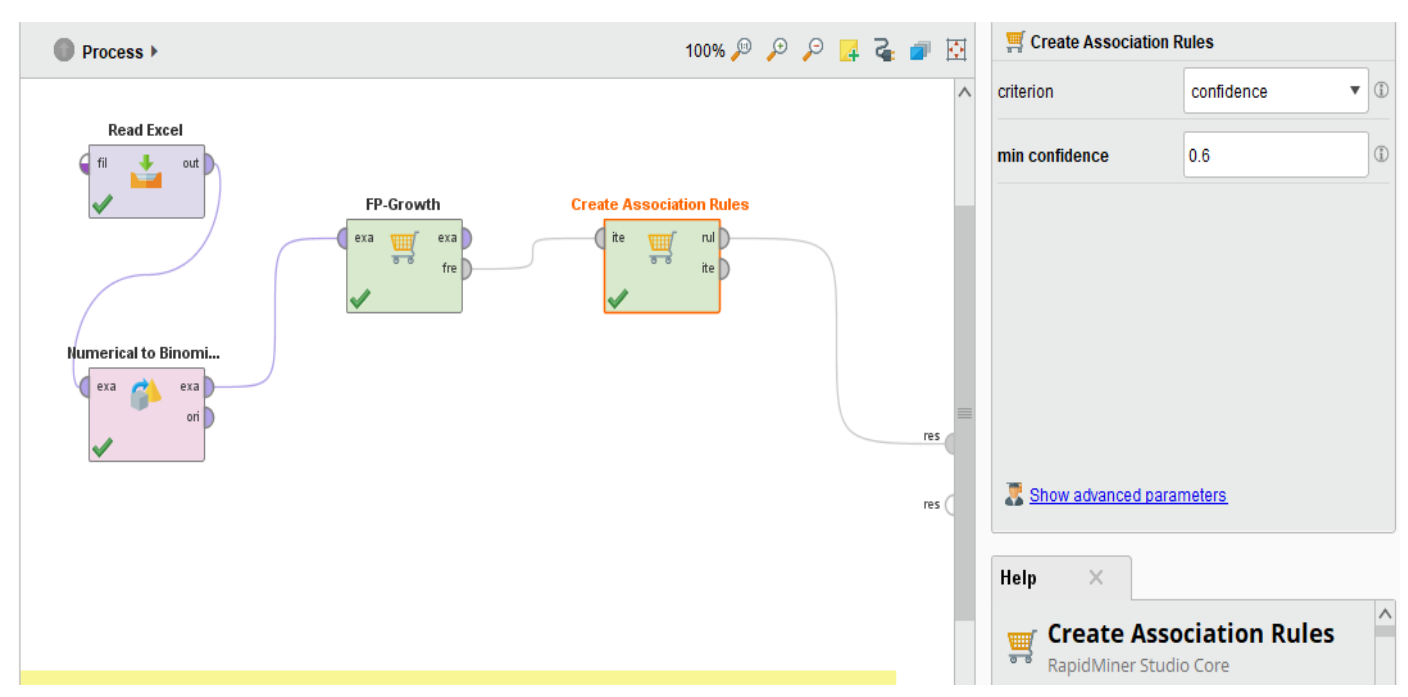

Gambar 3. Mengatur nilai minimal confidence

\section{KESIMPULAN}

Analisis asosiasi dengan menggunakan algoritma Apriori ini dapat membantu para pemangku kepentingan seperti manajer toko untuk membuat keputusan bisnis yang dapat membantu penjualan barang ditoko mereka. Untuk menentukan aturan asosiasi yang diambil, setelah melakukan analisis asosiasi, pada tahap akhir diperlukan perhitungan lift ratio untuk melihat kekuatan dari aturan asosiasi yang telah dibentuk. Berdasarkan hasil pengujian dengan menghitung lift ratio didapatkan beberapa aturan yang memiliki nilai ratio tinggi yaitu : $\{$ Mentega $\} \rightarrow\{$ telur $\}$ dengan 
nilai confidence 1 dan lift ratio 1.25 , \{telur $\} \rightarrow$ \{terigu\} dengan nilai confidence $75 \%$ dan lift ratio 1.25 , \{gula,terigu\} $\rightarrow$ \{telur\} dengan nilai confidence $100 \%$ dan lift ratio 1.25 , terakhir \{telur,terigu $\} \rightarrow$ \{gula\} dengan nilai confidence $100 \%$ dan lift ratio 1.25 . Seperti yang telah dicontohkan pada item \{mentega\} $\rightarrow$ \{telur\}, manajer toko dapat mengambil strategi untuk menyimpan mentega di dekat telur untuk meningkatkan penjualan. Selain menyimpan metega di dekat telur, manajer toko juga dapat memberikan diskon untuk pembelian kedua item tersebut.

\section{DAFTAR RUJUKAN}

Erwin. (2009). Analisis Market Basket Dengan Algoritma. Jurnal Generic, 4, 26-30.

Fauzy, M., rahmat S, K., \& Asror, I. (2016). Penerapan Metode Association Rule Menggunakan Algoritma Apriori Pada Simulasi Prediksi Hujan Wilayah Kota Bandung. Jurnal IImiah Teknologi Informasi Terapan, 2(3).

Han, J., Kamber, M., \& Pei, J. (2012). Data Mining: Concepts and Techniques. In San Francisco, CA, itd: Morgan Kaufmann. https://doi.org/10.1016/B978-0-12381479-1.00001-0

Kasus, S., Pt, P., Gunadi, G., \& Sensuse, D. I. (2012). PENERAPAN METODE DATA MINING MARKET BASKET ANALYSIS TERHADAP DATA PENJUALAN PRODUK BUKU DENGAN MENGGUNAKAN ALGORITMA APRIORI DAN FREQUENT PATTERN GROWTH ( FP-GROWTH ): 4(1).

Kusrini, E. T. L. (2009). Algoritma Data Mining. Yogjakarta: Andi.

Listriani, D., Setyaningrum, A. H., \& M.A, F. E. (2016). Penerapan Metode Asosiasi Menggunakan Algoritma Apriori Pada Aplikasi Pola Belanja Konsumen ( Studi Kasus Toko Buku Gramedia Bintaro ). Jurnal Teknik Informatika Vol 9 No. 2, Universitas Islam Negeri Jakarta, 9(2), 120-127. Retrieved from http://journal.uinjkt.ac.id/index.php/ti/article/view/5602/3619

santosa, B. (2007). Data Mining: Teknik Pemanfaatan Data untuk Keperluan Bisnis. Yogyakarta: Graha Ilmu.

Sepri, D., \& Afdal, M. (2017). ANALISA DAN PERBANDINGAN METODE ALGORITMA APRIORI DAN FP-GROWTH UNTUK MENCARI POLA DAERAH STRATEGIS PENGENALAN KAMPUS STUDI KASUS DI STKIP ASDZKIA PADANG. 1(1).

Wicaksana, I. W. S. (2013). Belajar Data Mining dengan Rapid Miner. Jakarta.

Widiastuti, D., \& Sofi, N. (2014). Analisis perbandingan Algoritma apriori dan fpgrowth pada transaksi koperasi. 8(01). 